\title{
Disrupted continental environments around the Devonian-Carboniferous Boundary: introduction of the tener event
}

\author{
Cyrille PRESTIANNI ${ }^{1 *}$, MARIE SAUTOIS ${ }^{2} \&$ Julien DENAYER $^{3}$
}

${ }^{1}$ Royal Belgian Institute of Natural Sciences, O.D. Earth and History of Life, rue Vautier 29, 1000 Brussels, Belgium; cprestianni@ naturalsciences.be.

${ }^{2}$ Carmeuse Research \& Technology, Boulevard de Lauzelles, 65, 1348 Louvain-la-Neuve, Belgium; marie.sautois@carmeuse.com. ${ }^{3}$ Liège University, Geology Department, Evolution \& Diversity Dynamics Lab, Quartier Agora, B18, Allée du Six-Août, 4000 Liège, Belgium; julien.denayer@ulg.ac.be.

* corresponding author

ABSTRACT. Recent refinements of the palynological stratigraphic scheme around the Devonian-Carboniferous Boundary in southern Belgium result in new questions on the effect of the Hangenberg Biocrisis on spores and on the validity of some 'biozones'. Verrucosisporites nitidus, the guide taxa of the last Devonian palynozone (LN zone) is lacking in many sections and its presence is only acknowledged in proximal settings. Hence the LN zone is considered as an ecozone rather than a biozone. Moreover, investigation of the uppermost part of the uppermost Famennian shows that the palynological assemblages is dominated by abnormal forms of Retispora lepidophyta, notably by R. lepidophyta var. tener which seems to be characteristic of this interval in Western Europe. It is thus proposed to introduce the global tener event as a potential marker of the Hangenberg Biocrisis on land and in proximal marine settings. This profusion of abnormal spores is thought to be related to climatic variation possibly in link with global cooling below the Devonian-Carboniferous Boundary.

KEYWORDS: Hangenberg Biocrisis, Strunian, Famennnian, Tournaisian, stratigraphy, bioevent, extinctions.

\section{Introduction}

The Devonian-Carboniferous Boundary (DCB) is associated with one of the most severe biocrises through the Phanereozoic, namely the Hangenberg Event or Hangenberg Biocrisis. Long considered as a second-order extinction event, this biocrisis is now regarded as equally severe as the global Late Frasnian Kellwasser Biocrisis as it led c. $45 \%$ of marine genera to extinction and wiped out entire ecosystems at the end of the Famennian Age (Becker et al., 2016 and references within). Research traditionally focused on the Devonian-Carboniferous Boundary, i.e. for the search for a basal Carboniferous GSSP and a biostratigraphic scheme, but high resolution data on extinctions all through the Hangenberg Biocrisis are still a work in progress, and mainly concern the marine realm (see the synopsis by Kaiser et al., 2015 and references within).

What happened on continents is less clear. The latest Famennian flora is traditionally seen as a homogeneous cover of "Archaeopteridalean forests" (Fairon-Demaret, 1986; Jarvis, 1990) that is associated to the homogeneous "lepidophyta palynoflora" (Streel et al., 2000) typical of that interval. This assemblage suffered from the biocrisis but did not become extinct before the DCB (Streel \& Marshall, 2006). Consequently, there is a marked time shift between the main extinction events in the marine and terrestrial realms, which points to clear differences on the effects of the biocrisis between both realms (e.g. McGhee, 2013). Timing of the events on lands still needs to be clarified and a revised palynological scheme of this critical interval is unavoidable. Moreover, recent data on plants (Decombeix et al., 2011a, b; Cascales-Miñana, 2014; Prestianni et al., 2015) tend to show that the traditional view of what happened on land at the DCB is incorrect.

Recent refinements of the palynological scheme near the DCB in southern Belgium raises new questions on the effect of the Hangenberg Biocrisis on palynological assemblages and on the validity of several 'biozones' still in use. This paper aims (1) to review the palynological zonation for the end of the latest Famennian of Belgium, (2) to compare the Belgian biostratigraphic succession with those established at the global scale, (3) to renew the interest of palynology for the establishment of the DCB, (4) and to briefly discuss the impact of the Hangenberg Biocrisis on the continents.

\section{Geological sections}

The most recent biostratigraphic scheme of the latest Famennian, based on interval and Oppel miospore zones was established for Sauerland (Germany) by Higgs \& Streel (1994) and Streel et al. (1987) and revised for the Ardennes in Dreesen et al. (1993) and Maziane et al. (1999). Four miospore zones cover the latest Famennian-earliest Tournaisian interval: the LL (R. lepidophyta - K. literatus) and LE (R. lepidophyta $-I$. explanatus) zones cover most of the Strunian (latest Famennian) interval. The DCB is considered to correspond roughly to the limit between the Strunian LN (R. lepidophyta $-V$. nitidus) zone and Hastarian VI ( $V$. verrucosus $-R$. incohatus) zone. The LE and LL zones are well known in the Ourthe area of Southern Belgium and were studied in details by Maziane et al. $(1999,2002)$. The LN zone has never been observed in the Namur-Dinant Basin but is known in proximal facies of the London-Brabant Massif (Menen borehole; Loboziak et al. 1994). The VI zone is only known from the upper member of the Hastière Formation, i.e. above a long interval almost devoid of spores (Van Steenwinkel, 1984).

In Belgium, the mixed carbonate-siliciclastic sedimentation typical of the uppermost Famennian (Strunian) follows the dominantly siliciclastic succession of the Famennian (Thorez et al., 2006; Denayer et al., 2015 for recent summary). Facies indicate an internal to median ramp environment under the influence of both detrital and marine inputs (Thorez \& Dreesen, 1986; Paproth et al., 1986; Van Steenwinkel, 1984, 1993). The Strunian heterolithic succession is included into the Comblainau-Pont Formation (Fm) in the northeastern part of the NamurDinant Basin (Condroz sedimentation area, Fig. 1) and Etroeungt Fm in the south and southwestern part (Dinant and Avesnois sedimentation areas) whereas in the Vesdre-Aachen sedimentation area (NE part of the basin), a third formation, the Dolhain Fm, is characterized by stromatoporoid biostromes alternating with marine shales. These three formations are lateral equivalent of each other and their composition shows a proximal-distal gradient oriented NE-SW (Thorez et al., 2006). These formations are succeeded by the purer carbonate of the Hastière Fm which is the oldest Carboniferous formation in the basin (Hance \& Poty, 2006). However, at its base one bed includes Devonian faunas (quasiendothyrid foraminifers, campophyllid corals, phacopid trilobites) and detrital grains. The reworked aspect of these faunas is debated (Van Steenwinkel, 1993; Casier et al., 2004). But this basal bed yields a fauna that is still clearly Devonian in age. The following beds typically yield depauperate Tournaisian assemblages of foraminifers, corals and brachiopods. 

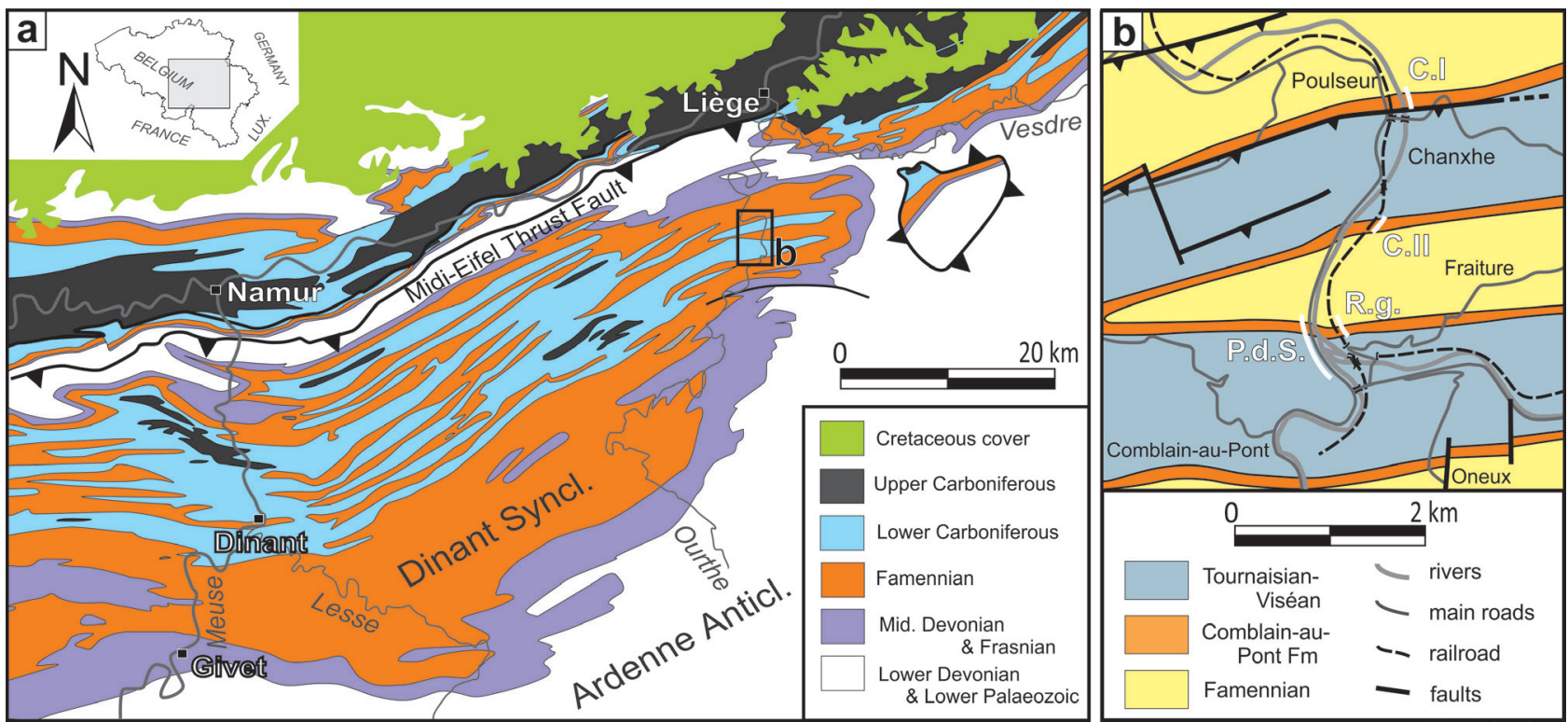

Figure 1. Geological map of Southern Belgium (redrawn from de Bethune, 1954); b: close-up view of the studied area. Abbreviations: CI: Chanxhe I section, CII: Chanxhe II section, P.d.S.: Pont-de-Scay section, R.g.: Rivage (gare) section.

The current marker of the base of the Carboniferous - i.e. the conodont Siphonodella sulcata - is not present in Belgian sections (Van Steenwinkel, 1984). The DCB is "traced by using a negative criterium, namely by the disappearance of the Devonian fauna, rather than by a positive one which would be the beginning of the Carboniferous fauna" (Conil et al., 1986). The boundary is thus traditionally determined in Belgium by the disappearance of typically Devonian microfossils (quasiendothyrid foraminifers, Crytophyllus) and macrofossils (campophyllid corals, phacopid trilobites, Sphenospira julii and Araratella moresnetensis brachiopods)

This paper focuses on two sections situated in the proximal NE part of the Condroz sedimentation area, in the Ourthe valley (Fig. 1). The Pont-de-Scay section is situated on the left bank of the Ourthe river (facing the Rivage Gare section, no longer accessible), along the road between Comblain-au-Pont and Esneux, south of Liège. It has an almost continuous exposure of the upper Famennian Evieux Fm, the uppermost Famennian Comblain-au-Pont Fm (Fig. 2), and the Tournaisian Hastière Fm and continues upstream up to the lower Viséan formations.

The lower part of the Comblain-au-Pont Fm (beds 54-56) is made of silty shales with intercalated carbonate beds and lenses. Beds 57 to 61 show the increase of carbonate content up-section and crinoids become abundant in mixed calcareousargillaceous facies. The interval between bed 62 and 73 is composed of multi-decimetric beds of bioclastic and crinoidal packstone alternating with multi-decimetric beds of silty shales, occasionally micaceous. It is followed by crinoidal limestone containing a variable content of clay (beds 74 to 84 ). Beds 85 87 are dominantly made of greyish shales with plant fragments, interrupted by two limestone horizons respectively. These two horizons are correlated with beds 156 to 158 of the Chanxhe section. The rest of the formation (beds 88 to 100 ) is dominated by multi-decimetre-thick beds of bioclastic and crinoidal packstone to grainstone with some thin shaly interval. Brachiopods, large crinoid stems and corals (Palaeosmilia aquisgranensis and Campophyllum flexuosum) are rather common in this last unit. The first bed of the Hastière Fm (bed 101) is a $110 \mathrm{~cm}$-thick unit of massive bioclastic packstone-grainstone. The facies remains very similar up-section except bed $102 \mathrm{~d}$ that is argillaceous and sub-nodular. The faunal change occurs above bed 101 with disappearance of Devonian fauna such as Quasiendothyra, Cryptophyllus and Campophyllum.

The renowned Chanxhe section (Chanxhe I) is situated on the right bank of the Ourthe river, $2.5 \mathrm{~km}$ north of the Pont-de-Scay section. It has been intensively studied (Conil, 1964; Streel, 1966;
Bouckaert et al., 1970; Becker \& Bless, 1974; Maziane et al., 2002; Casier et al., 2005; etc.) despite the fact that the DCB is not exposed because a fault cuts out the last c. $4 \mathrm{~m}$ of the Comblain-auPont Fm. The sampled interval (based on Maziane et al.'s (2002) samples) starts at bed 111, the first thick carbonate horizon that yields the first stromatoporoids and brachiopods. It also yielded conodont fauna typical of the lower part of the Bispathodus ultimus - equivalent to the upper expansa - conodont zone of Ziegler \& Sandberg (1990), and thus to the base of the Strunian substage as suggested by Streel \& Hartkopf-Fröder (2005). This bed is topped by grey siltstone containing several sandy horizons and showing convolute bedding at its top. The next carbonate bed (113) yields the first Quasiendothyra kobeitusana kobeitusana foraminifers (Conil, 1964). The following unit (beds 113 to 155) correspond to a cyclic succession of bioclastic sandy grainstone or crinoidal sandstone alternating with siltstone or shaly siltstone with a calcareous cement. The amount of detrital quartz grains decreases up-section. The carbonate beds are rather rich in large bioclasts of crinoids, brachiopods, gastropods and rugose corals. The first occurrence data of the acritarch Gorgonisphaeridium winslowiae has been noted in bed 123 (Maziane \& Vanguestaine, 1997). The rest of the section is dominated by bioclastic grainstone or packstone with few detrital quartz grains and a rich fauna of brachiopods, corals, crinoids and foraminifers. Several shaly occurrences are sufficiently characteristic to be used as correlation levels with neighbouring sections (see Fig. 2)

\section{Description of the miospore assemblage from the Pont-de-Scay section}

To complement the detailed studies carried on the Chanxhe section by Maziane et al. $(1999,2002)$, the top of the Comblainau-Pont Fm was sampled in the Pont-de-Scay section (Poty et al., 2011). Twelve samples have been processed from beds 55 to 94. Most of them yielded assemblages with abundant and well diversified miospores and acritarchs. The state of preservation of the miospores is variable throughout the section being progressively less good toward the top.

A range chart of selected miospores of the Pont-de-Scay section is provided in Figure 3. Spore species have been selected based either on their abundance in the assemblage or as they are easily recognizable taxa providing accurate stratigraphic information. The identification of several zonal index species in the miospore zonations currently in use (Maziane et al., 1999) allowed us to highlight two assemblages.

The first assemblage concerns the six lowest samples B65B79. Particularly diverse, it is characterized by the presence 


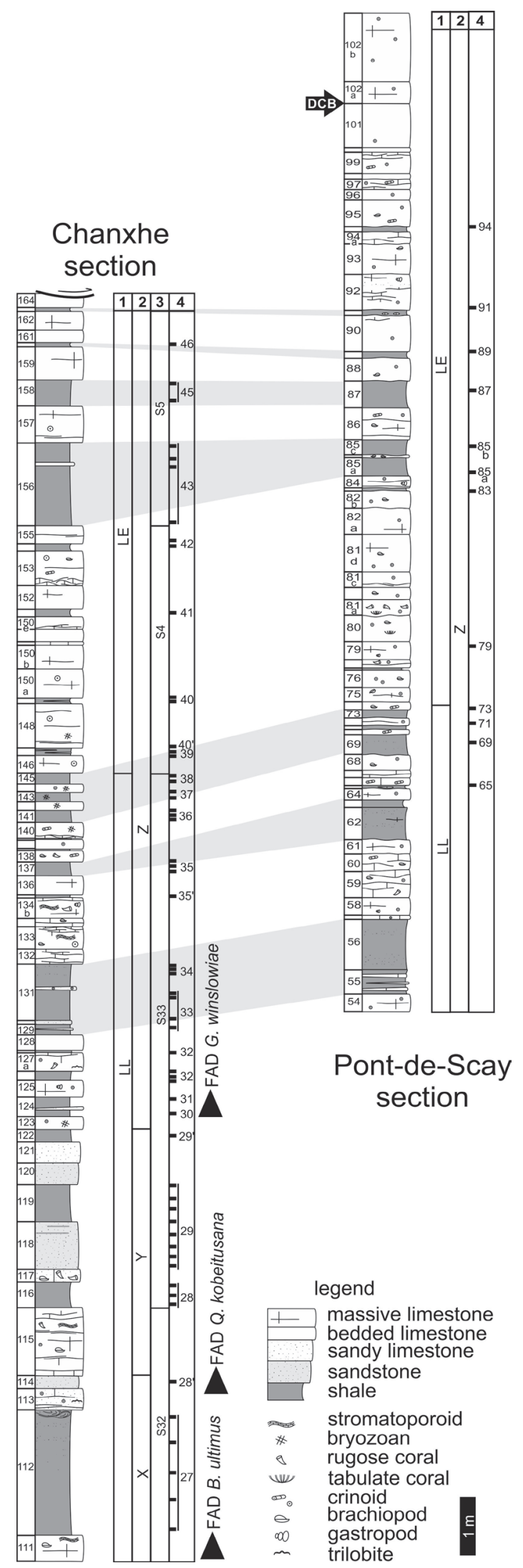

Figure 2. Lithological and lithostratigraphic columns of the Chanxhe and Pont-de-Scay sections. Bed numbering after Conil (1964). Data for the Chanxhe section are from Maziane et al. (1999, 2002). Legend: 1: palynological zones; $R$. lepidophyta biometric zones of Maziane et al. (2002); 3: miospores/acritarchs diversity sequences of Maziane et al. (1999); 4: position and numbering of samples (see Maziane et al. (1999, 2002) for Chanxhe section). DCB: Devonian-Carboniferous Boundary (based on faunal change, see section 2), FAD: first appearance datum for the conodont Bispathodus ultimus, the foraminifer Quasiendothyra kobeitusana kobeitusana and the acritarch Gorgonisphaeridium winslowiae. of Retispora lepidophyta var. lepidophyta and the abundant presence of R. lepidophyta var. minor. The assemblage is as well characterized by the presence of several member of the Diducites morphon as defined by Van Veen (1981b) that are D. mucronatus and $D$. versabilis. Diducites plicabilis is apparently lacking and D. poljessicus is only presented by a single occurrence in bed 69 (Fig. 3). Interestingly, D. plicabilis has been interpreted by Streel (1999) and Streel \& Scheckler (1990) as specifically representing the Rhacophyton isospore and its environment the "(coal) swamp". Among the very abundant spores (Fig. 4) are the murornate forms such as Convolutispora sp. and Corbulispora cancellata, verrucate forms such as Lophozonotriletes concentricus, Tumulispora malevkensis and Verrucosporites sp. and the forms with prominent sculptures such as Raistrickia variabilis and the apiculate form Pustulatisporites dolbii. The other taxa represented are Apiculiretusipora verrucosa, Cristatisporites matthewsii, Dictyotriletes trivialis, Gorgonispora crassa, Grandispora gracilis, G. tamarae, Knoxisporites literatus, Rugospora radiata, Tumulispora rarituberculata, and T. variverrucata (Figs 4, 5). Within these six samples, bed 75 has to be highlighted. It is characterized by a particularly diversified assemblage marked by the dominant occurrence of Vallatisporites hystricosus and the presence of Vallatisporites vallatus. The incursion of these species, as well as the observed diversity in the verrucate forms Tumulispora and Verrucosiporites, can be interpreted as the record of short-lasting distinct environmental settings.

The second assemblage, comprising five samples between beds 83 and 94 (Figs 3, 4) is less diverse than the first one. A progressive reduction in diversity is observed toward the top of the studied section. Most characteristic spores of the preceding assemblage are absent from these five sampled beds. Among the noticeable absences are the Diducites morphon only represented by a single Diducites versabilis spore at bed 94 . The representatives of the genus Grandispora are progressively less abundant with only Grandispora tamarae being represented in the first two beds. Similarly, Lophozonotriletes concentricus is only present in the first three beds. Spores that were recorded as abundant in the first assemblage such as Tumulispora malevkensis, Verrucosiporites or Apiculiretusispora verrucosa are rare in this second assemblage. By contrast however, Pustulatisporites dolbii and Raistrickia variabilis remain present in all productive samples. The latter presents a noticeable morphological variability that will be discussed later. Finally species unknown in the first assemblage appear such as Indotriradites explanatus, Bascaudaspora mishkinensis and Apiculiretusispora plicata. It is however further important to note that $R$. lepidophyta is marked by a strong morphological variation within this interval. A progressively increase in size of the population with an atypical form characterized by an interrupted reticulum is observed (Fig. 5). These spores form up to $95 \%$ of the bed 94 . In this last bed, typical R. lepidophyta form less than $5 \%$ of the population and less than $1 \%$ of the whole assemblage (Fig. 3). The morphological changes are so profound that a new genus could be established if all intermediate stages were not observed. A similar pattern was observed within Raistrickia variabilis. Present in nearly all studied samples, this species is marked in the two highest sampled beds (91 and 94) by strong distortion in the overall shape and ornamentation (Fig. 5). Less obvious but also noticeable, Pustulatisporites dolbii is also marked in the two highest sampled beds by atypical forms with distinct morphologies and abnormal ornamentations (Fig. 6).

\section{Miospore assemblage interpretation}

Retispora lepidophyta (Kedo) Playford is present in all studied samples. This species is undoubtedly one of the most important index species of the late and latest Famennian. It is characterized by a short stratigraphic range and a very characteristic morphology (Maziane et al., 1999). Its range in Western Europe has traditionally been divided in three Oppel zones that are the Retispora lepidophyta - Knoxisporites literatus (LL) zone, the Retispora lepidophyta - Indotriradites explanatus (LE) zone and 


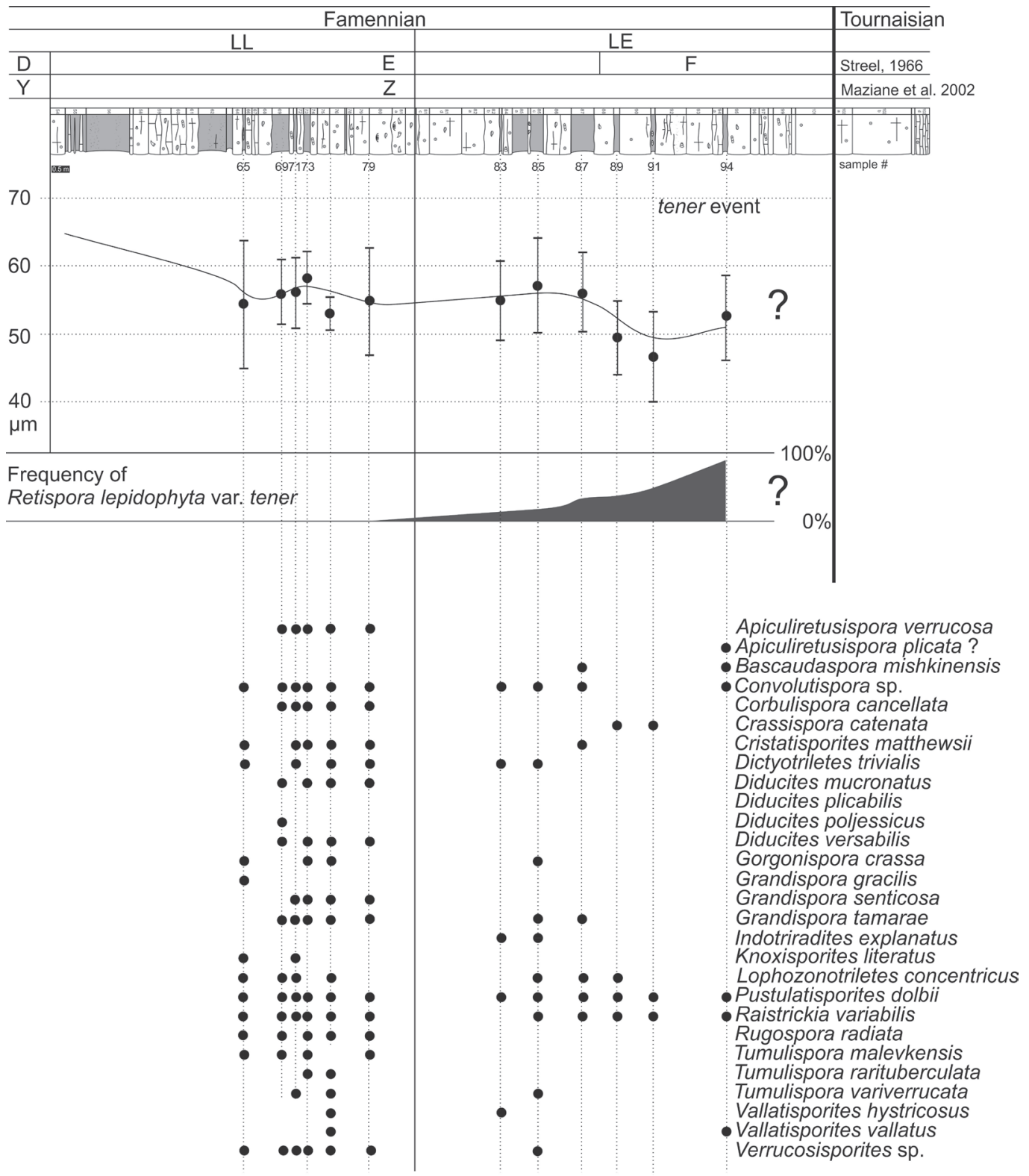

Figure 3. Stratigraphic ranges of selected dominant miospore species identified in the uppermost Famennian of the Pont-de-Scay section and quantification of abnormal forms (R. lepidophyta var. tener) at the top of the Devonian, defining the tener event.

the Retispora lepidophyta - Verrucosisporites nitidus (LN) zone. The occurrence of the index species Knoxisporites literatus as well as the income of Retispora lepidophyta var. minor allow us to attribute the first assemblage to the LL Oppel zone. The interval covered by the first assemblage further corresponds to the beginning of $R$. lepidophyta minor Acme zone thus to the upper part of the LL Oppel zone that has been correlated with the Upper expansa conodont zone.

The second assemblage occurs above a ten meter unit of limestones barren in spores. It is characterized by the occurrence of the index spore Indotriradites explanatus. The first occurrence of the latter marks the base of the LE Oppel zone to which we attribute the second assemblage. This spore is however rare and only occurs in beds 83 and 85 . The LL/LE biozone boundary is placed arbitrarily at the base of bed 74 , at base of the ten meters of limestones barren in spores.

After the observation of clear morphological changes within $R$. lepidophyta through its range by Kedo (1957), these variations were quantified through the biometric analyse of Streel (1966). It resulted in the subdivision of the stratigraphic range of the spore in four biometric zones $(\mathrm{C}-\mathrm{F})$. This scheme was later refined by Maziane et al. (2002) and led them to define five slightly different biometric zones $(\mathrm{V}-\mathrm{Z})$. The main difference existing between them is the exclusive use by Maziane et al. (2002) of biometric characters (mainly spore diameter) to distinct the different zones whereas Streel (1966) proposed a combination of morphological and biometrical characters. The latter author indeed highlighted that $R$. lepidophyta was not only varying in size but also morphologically through the appearance of atypical forms. He defined the so called type a form of $R$. lepidophyta that is characterized by a disappearance of the muri of the reticulum reduced in the more extreme forms to a few crests and verrucae (Streel, 1966).

Both schemes have been applied to this section (Fig. 3). The comparison between the two systems shows that the biometric zones C and D of Streel (1966) roughly correspond to respectively the $\mathrm{X}$ and $\mathrm{Y}$ biometric zones sensu Maziane et al. (2002). However, the $\mathrm{Z}$ zone is subdivided in the Streel (1966) model between the $\mathrm{E}$ and $\mathrm{F}$ biometric zones based on the appearance (E) and subsequent dominance of the atypical form type a (F) (Fig. 6).

The absence in the succession of Verrucosisporites nitidus precludes the identification of the LN Oppel zone precisely characterized by the appearance of that spore. This absence is discussed below. 


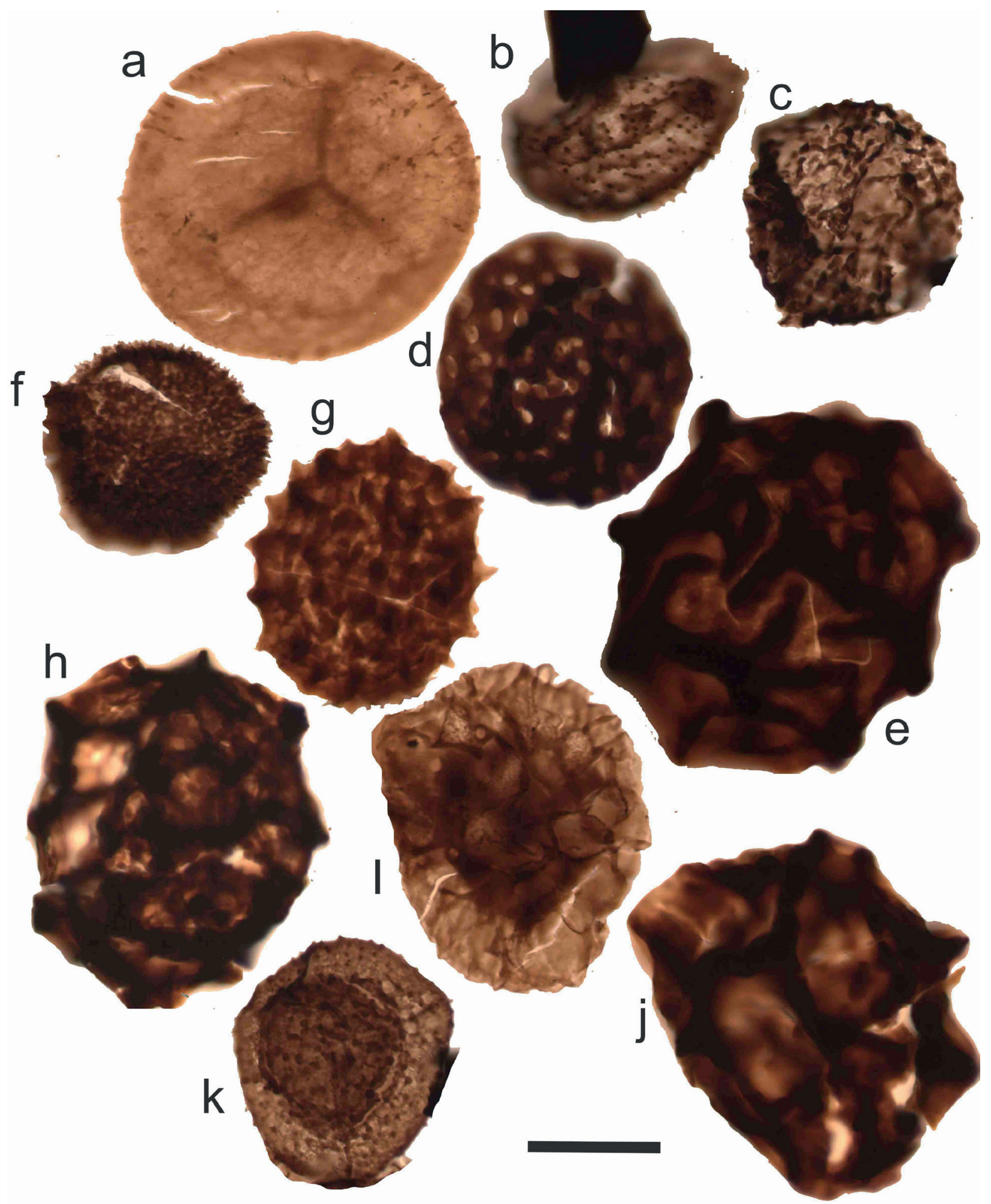

Figure 4. Selected dominant miospores species from the uppermost Famennian of the Pont de Scay section; a: Apiculiretusispora verrucosa, Ulg72236,B.71; b: Apiculiretusispora plicata, ULg-72245, B.94; c: Bascaudaspora mishkinensis, ULg-72243, B.89; d: Convolutispora sp., ULg-72269, B.85B; e: Corbulispora cancellata, ULg-72237, B.73; f: Crassispora catena, ULg-72242, B.87; g: Cristatisporites matthewsii, ULg-72237, B.73; h: Dictyotriletes trivialis, ULg-72235-C32B, B.69; i: Didicites versabilis, ULg-72236, B.71; j: Gorgonispora crassa, ULg-72236, B.71; k: Indotriradisporites explanatus, ULg-72215, B.79. Scale bar $=30 \mu \mathrm{m}$.

\section{Where is the LN Oppel zone?}

The Retispora lepidophyta - Verrucosisporites nitidus Oppel zone is exclusively based on the appearance of Verrucosisporites nitidus. The identification of this spore has been the subject of many debates (Turnau et al., 1994). The genus Verrucosisporites is indeed characterized by variously verrucate spores all falling within a continuous morphological range. Turnau et al. (1994) redefined the species and discussed its distribution. Though considering how important this species is as an index species for the highest part of the latest Famennian, they considered the possibility of its diachronous first appearance. But in many regions, biostratigraphic data tend to show that $V$. nitidus - where correctly identified - appears at the same stratigraphic level (Turnau et al., 1994). However, a diachronous occurrence has been documented in Western Pomerania where the spore appeared already in slightly older strata (LL zone, Stempien Salek, 2002).

Verrucosisporites nitidus is difficult to distinguish from other species of the genus. Filipiak (2004) intensively studied the Devonian-Carboniferous transition of the Holy Cross Montains and could only locate the species in the subsequent VI biozone. 

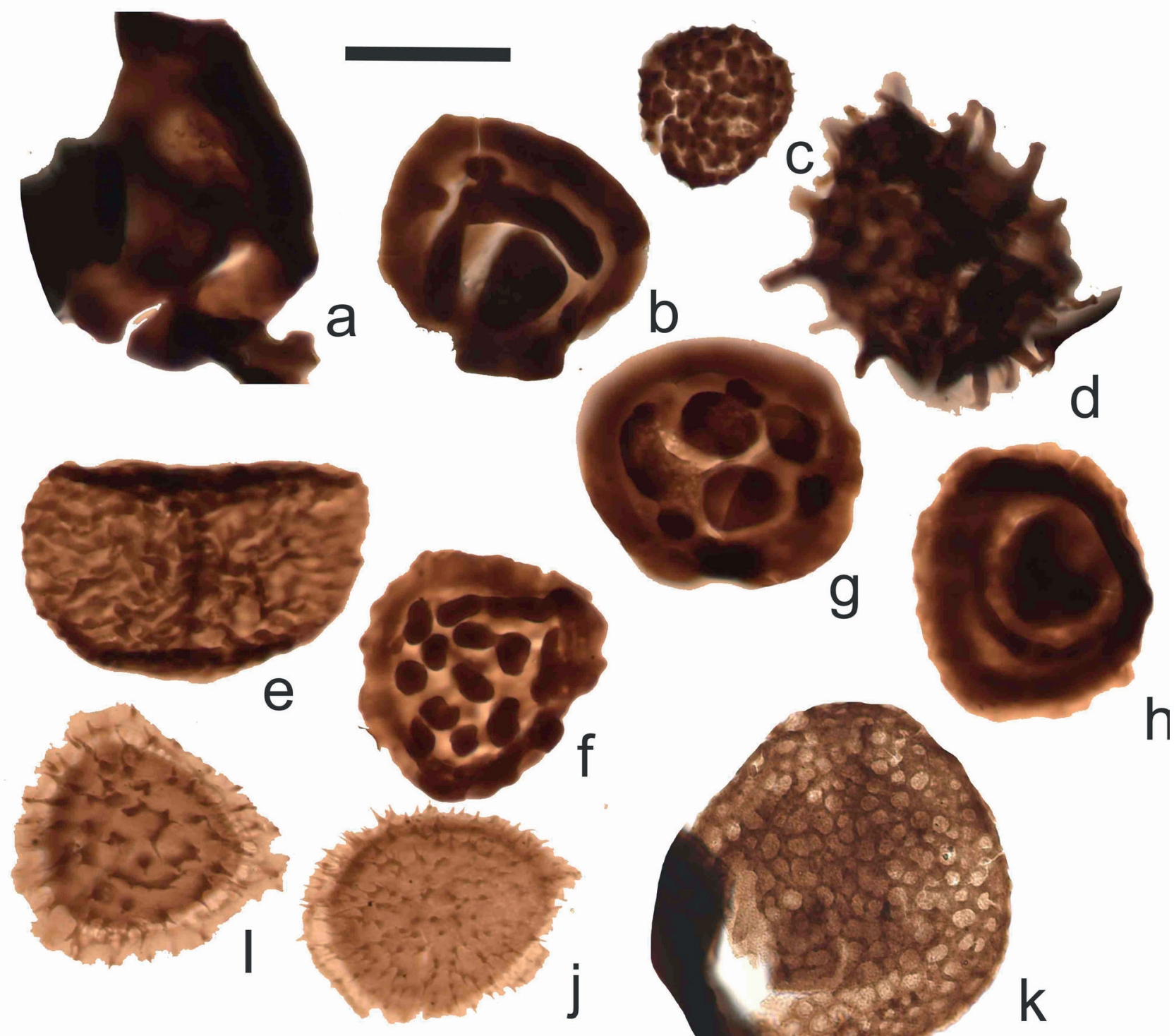

Figure 5. Selected dominant miospores species from the uppermost Famennian of the Pont de Scay section; a: Knoxisporites literatus, ULg-72208-N33, B.65; b: Lophozonotriletes rarituberculata, ULg-72238, B.75; c: Pustulatisporites dolbii, ULg-72241, B.85B; d: Raistrickia variabilis, ULg-72238, B.75; e: Rugospora radiata, ULg-72237, B.73; f: Tumulispora malevkensis, ULg-72236, B.71; g: Tumulispora variverrucata, ULg-72235, B.69; h: Tumulispora concentricus, ULg-72236, B.71; i: Vallatisporites hystricosus, ULg-72237, B.73; j: Vallatisporites vallatus?, ULg-72237, B.73; k: Retispora lepidophyta, ULg-72207, Nv. 7. Scale bar $=30 \mu \mathrm{m}$.

Similarly, in the Russian Platform, V. nitidus is rarely encountered before the DCB (Byvsheva et al., 1984). In Belgium, it has notably only been recorded in one single level in the Menen borehole (London-Brabant Massif, proximal facies, Loboziak et al., 1994). Whereas the lack of $V$. nitidus in the succession studied herein is consistent with all up to now investigated sections showing the DCB in the Dinant Synclinorium (Maziane et al., 2002; see also discussion in Streel, 2015). Two hypotheses could be made. The first is that the whole biozone is lacking due to a stratigraphic hiatus. The second is that the spore $V$. nitidus is lacking from these deposits leading to an extension of the LE Oppel zone up to the DCB. A closer look at Figure 3 helps tentatively answering this question. The assemblage shows a clear change between the base and the top of the section. The levels here interpreted as part of the LE biozone are characterized by a low diversity and the progressive disappearance of many of the 'heavier' spore genera (Fig. 7). It is notably the case of Lophozonotriletes, Tumulispora or Verrucosisporites. This change corresponds also to a lithological change from a siliciclastic-dominated succession in the lower part to a carbonate-dominated succession in the upper part of the Pont-de-Scay section, suggesting a deposition under more marine conditions. The Menen borehole (Loboziak et al., 1994) is conversely dominated by siliciclastics up to the top (in which limestone intercalations occur). The palaeogeographic situation of that borehole places it closer to the palaeocontinent (Fig. 7). We here suggest that the absence or scarcity of $V$. nitidus in the Namur-Dinant Basin is due to distinct palaeoecological configurations. The environment where the plant producing $V$. nitidus could have been simply absent or particularly rare (in addition to the small size of the spore) from the source regions of the sediments registered in that part of the basin. The first hypothesis (hiatus) is therefore not supported by any biostratigraphic evidence as discussed below.

\section{Biozones vs. ecozones}

Since the LN zone of previous authors is considered here to be time-equivalent to, and thus put in parallel with the upper part of the LE biozone (see also Streel et al., 2013), it seems logical to reevaluate its validity as a biozone. As explained above, V. nitidus, the guide taxa of the LN zone is lacking in several DCB sections and is only present in (very) proximal settings. We think that this distribution is linked to ecological factors (presence or absence of the plant) and/or to the distance from the source. Firstly, it is important to keep in mind that spores are transported plant parts. As such, they are particularly influenced by the ecological 

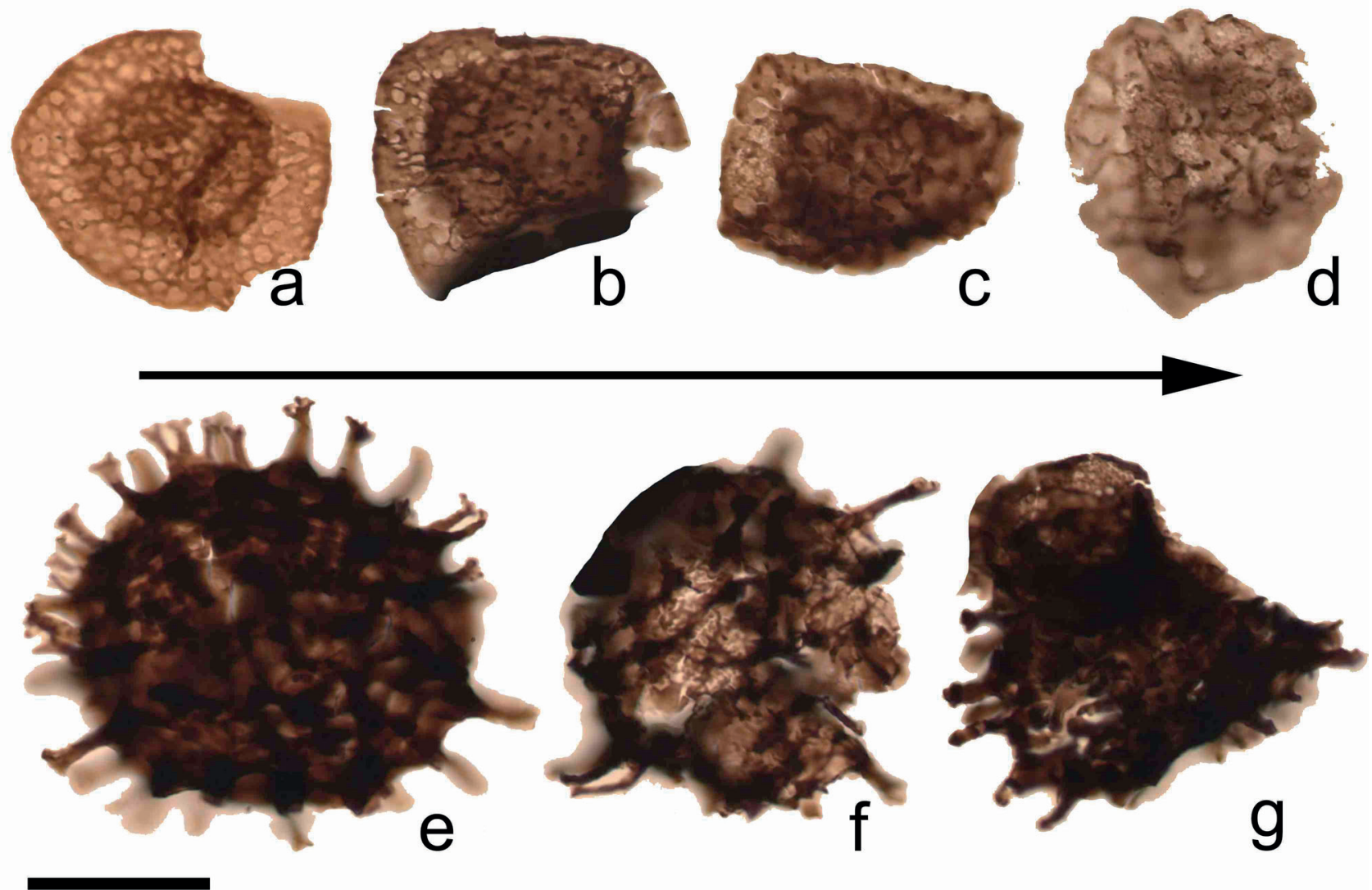

Figure 6. Example of morphological variations observed among R. lepidophyta (a-d) and Raistrickia variabilis (e-g) within the tener event (uppermost Famennian) in the Pont de Scay section. a: Retispora lepidophyta var. minor, ULg-72237, B.73; b: Retispora lepidophyta var. tener, ULg-72242, B.87 (example of an intermediary form); c: Retispora lepidophyta var. tener, ULg-72242, B.87 (example of an intermediary form); d: Retispora lepidophytra var. tener, ULg-72242, B.87; e: Raistrickia variabilis, ULg-72215, B.79 (example of a normal form); f-g: Raistrickia variabilis, ULg-72243, B.89 (examples of abnormal forms). Scale bar $=30 \mu \mathrm{m}$.

settings (climate, hydrography etc.). Secondly, their transport is not uniform, each spore acts as a sediment particle and is thus submitted to sorting. Interestingly, the upper part of the considered interval is dominated by presumably light camerate spore taxa and completely lack 'heavier' forms such as the verrucate taxa. The LN biozone could therefore rather correspond to an ecozone reflecting local conditions. Its biostratigraphic potential could consequently be very limited and its absence should not be interpreted as witnessing a gap in the sedimentary record. The second argument to re-evaluate the LN zone is its occurrence within a clearly impoverished (both in diversity and number of specimens) assemblage in which abnormal forms are relatively abundant in most sections. Again, this pleads for an ecological effect, possibly reflecting the Hangenberg Biocrisis on continents. One should note that this depleted assemblage is not a taphonomic artefact as it is not facies dependant. Indeed in Belgium, the disrupted assemblage occurs within a carbonatedominated succession at the top of the Comblain-au-Pont Fm, even if the carbonate depiction starts earlier. In Southern Ireland (Higgs et al., 1988; Van Veen, 1981b) it occurs in a siliciclastic sequence where no major facies change is noted. Similarly, in the Holy Cross Mountains, no major facies shift is observed (Filipiak, 2004).

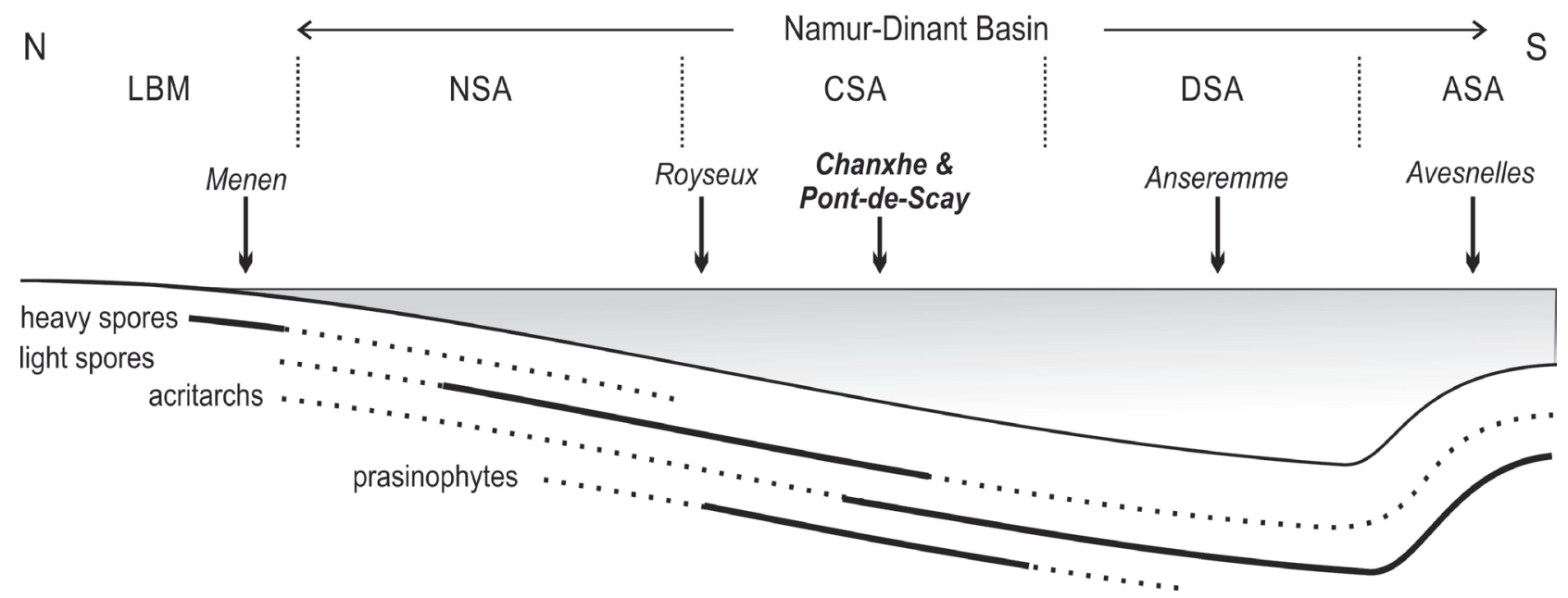

Figure 7. Schematic proximo-distal transect through the Namur-Dinant Basin with distribution of 'heavy' spores (i.e. Verrucosisporites nitidus), 'light' spores (i.e. Retispora lepidophyta), acritarchs and prasinophytes during the latest Famennian LE biozone times. Solid lines indicate abundance, dotted lines indicate lower occurrence. Abbreviations: ASA: Avesnois sedimentation area, CSA: Condroz sedimentation area, DSA: Dinant sedimentation area, LBM: London-Brabant Massif (continent), NSA: Namur sedimentation area. No scale. 


\section{A disturbed end-Devonian palynofloral event: the tener event}

Combaz \& Streel (1971) described for the first time the occurrence of abnormal spore assemblages in the Brevilliers drillhole (northern France), below the DCB. Similar abnormal palynoflora has been described from the uppermost Famennnian of Hasselbachtal (Sauerland, Germany; Higgs \& Streel, 1994), the Holy Cross Mountains (Poland; Filipiak \& Racki, 2010) and in various localities of the Russian Platform (Chibrikova et al., 1978). Up to now, it has not been noted as such outside Europe but as Filipiak \& Racki (2010) concluded, it has to be found in other localities. However, one should note that this abnormal assemblage, often coupled with a depletion in biodiversity of spores, is possibly a marker of the Hangenberg Biocrisis on continents.

In other regions, if attention was not paid to abnormal variations among all taxa, the occurrence of strongly altered Retispora lepidophyta morphologies has been repeatedly reported. Kedo $(1957,1963)$ was the first to point out both the stratigraphic importance of Retispora lepidophyta and its morphological variability establishing $R$. lepidophyta var. tener and minor. Streel (1966) followed a similar philosophy and established $R$. lepidophyta type $a$. Though a thorough revision of the morphological variation of $R$. lepidophyta as well a reevaluation of its taxonomy is necessary. Chibrikova et al. (1978) briefly discussed the morphology of $R$. lepidophyta var. tener. Accordingly, it is in our opinion reasonable to consider that the R. lepidophyta type a of Streel (1966) and the R. lepidophyta var. tener Kedo (1963) represent the same morphological variant. Both authors mention an increase in what they call abnormal forms close to the DCB. The occurrence of the type a form has subsequently been observed and highlighted in most 1970's records and always just below the DCB (Dolby and Neves, 1970; Gayer et al., 1973; Neves \& Dolby, 1967; Paproth \& Streel, 1970; Turnau, 1975, 1978). Others mention the breakdown of the muri of $R$. lepidophyta in the last beds of the Famennian (Higgs, 1975; McGregor, 1970; Playford \& McGregor, 1993). Similarly, former USSR palynologists repeatedly noticed the occurrence of abundant populations of this abnormal form of $R$. lepidophyta just before the DCB (Avkhimovitch et al., 1988; Barskov et al., 1984). Considering the important role of $R$. lepidophyta var. tener in the determination of that event as well as the wide area covered by the observation, we propose to name as "tener event" the occurrence of large population of abnormal spores just before the DCB. The tener event possibly corresponds to the consequences of the Hangenberg Biocrisis on the continents.

The origin of the abnormal spores has been detailed and discussed by Filipiak \& Racki (2010) and only a short summary is provided here. Living plants produce a small percentage of pollen grains considered to be abnormal and not viable as part of a natural variation (Pozhidaev, 2000). Higher percentages of abnormal forms ( $>3 \%$ after Foster \& Afonin, 2005) cannot be explained by natural variation and it requires external mutagen factors. Such factor are basically environmental (hydric stress, high temperature, increased $\mathrm{CO}_{2}$ atmospheric content; Mulcahy, 1981; Koti et al., 2005), pollution (heavy metal, acid rain; Visscher et al., 2004; Foster \& Afonin, 2005) and UV-B radiation (stratospheric ozone destruction).

Filipiak \& Racki (2010) invoked the volcanic activity as a potential source of mutation leading to an abnormal palynological association in the uppermost Famennian from the Holy Cross Mountains. Since no convincing large scale volcanism event is known in the uppermost Famennian, intrinsic factors, such climatic fluctuations and notably cooling and resulting droughts, is preferred to explain the phenomenon.

\section{Continental biocrisis or extinction event?}

Contrasting viewpoints exist today concerning the effect of the Hangenberg Biocrisis on continental ecosystems (CascalesMiñana, 2014; Kaiser et al., 2015). Basing their analyses on a comprehensive family-level dataset, Cascales-Miñana (2014) concluded that there was no evidence for a great extinction event for plants at the DCB. By contrast, Kaiser et al. (2015) list several facts in order to support the idea of a mass extinction in continental ecosystems. They base their argumentation on the disappearance of the so-called Retispora lepidophyta 'flora' - better called Retispora lepidophyta palynological assemblage and of the so-called 'Cyclostigma-Archaeopteris forests'. It is however important to separate macrofossil and palynomorphbased arguments.

Plant localities are rare in the latest Devonian and almost lacking for the lower part of the Tournaisian (Decombeix et al., 2011b). The available information however contradicts the idea of a severe crisis within continental ecosystems. Indeed, accumulating data tend to highlight that the diversification of lignophytes had already started in the latest Devonian (Decombeix et al., 2011a, b; Prestianni et al., 2010). There is subsequently a depositional and/or sampling gap of almost 5 million years after which lignophytes appear diversified and well established in the upper Tournaisian. This gap, parallel to the Roemer's gap of vertebrates, hides a large part of land plant evolution (cf. McGhee, 2013). We postulate that beside the disappearance of Archaeopteris there has been a continuous diversification of lignophyte taxa before and after the DCB. The available information for other plant taxa such as ferns (e.g. Zygopteridales, Cladoxylales, Stauropteridales) and lycophytes indicate similar continuous diversification (Prestianni \& Gerrienne, 2010; Prestianni et al., 2015).

The palynological information is more complete though more difficult to interpret than the macrofossil data. Latest Famennian palynological assemblages are dominated by the spore Retispora lepidophyta that in some cases represents up to $50 \%$ of the assemblages (Streel et al., 2000). The plant producing that spore has been interpreted as adapted to coastal swamp environments. The disappearance of a spore representing such an important contribution is a notable discovery. However, a closer look at the assemblages immediately following the DCB namely the VI palynozone does not reveal a loss of diversity but rather an increase (Higgs et al., 1988). There is a clear loss of several Devonian taxa such as Diducites spp., Rugospora radiata or Vallatisporites pusillites. Interestingly, Van Veen (1981a) proposed a quantitative analysis of the evolution of selected spore taxa around the DCB in Ireland. This analysis has been performed at the Infraturma level allowing distance from taxonomic biases. Though out of date, this study clearly shows an important but short lasting perturbation at the DCB. After this perturbation, assemblages seem to recover very fast. The available palynological information is thus in contradiction with the hypothesis of a severe crisis on continents.

The DCB is marked by important and complex climatic changes (Streel et al., 2000; Streel \& Marshall, 2006; Kaiser et al., 2015). As noticed by Maziane \& Vanguestaine (1997) an important diminution in acritarch diversity, replaced by abundant prasinophytes are observed within the uppermost Famennian. They have been interpreted as marking a general cooling (Streel, 2015). Similar changes in micropalaeontological diversity have been noticed in the sections studied here. We moreover interpret the impoverished palynological assemblage from the top of the section as reflecting these climatic changes. The rarefaction of 'heavier' spores is, in our opinion, linked to a diminution of the continental runoff and thus translates to drier conditions. A cooler and drier climate has been repeatedly proposed for the end of the Devonian (Streel \& Marshall, 2006 and references within).

The climatic changes had dramatic impact on marine environments leading to a major diversity crisis (Algeo \& Scheckler, 1998). On continents however, though important modifications can be observed, there is no direct impact of the Hangenberg Biocrisis on the general diversity. Continental ecosystems, even if affected by important environmental changes are more resilient to such events (Cascales-Miñana, 2014; Traverse, 1988). The existence of refugees as well as the 
continuous interplay between highland and lowland floras are possible explanations for this (Decombeix et al., 2011b). Though an important depositional gap hampers firm affirmations, a continuous diversification of continental floras seems to occur between Late Devonian and Viséan deposits. The palynological data, seemingly less affected by this depositional gap moreover indicate a persistent diversification of spore and pollen taxa before and after the DCB.

The macrofloral crisis is in our opinion a misleading impression caused by the disappearance of emblematic Late Devonian assemblages (ecosystems) and the ecological reorganisation as consequence of deep environmental modifications around the DCB. An argument supporting this view is the disappearance of the hystricospores at the DCB (Alpern \& Streel, 1973; Higgs et al., 1988). Spores with multifurcate appendages have been associated to reproduction in aquatic conditions (swamp; Kar \& Dilcher, 2002). Their disappearance at the DCB can be interpreted as marking the rarefaction of coastal swamps around the DCB. The latter environment, although belonging to a distinct microenvironment (Streel, 1999), was very likely associated to the so-called 'Cyclostigma-Archaeopteris forests' that also disappeared at the DCB.

\section{Conclusions}

The revision of the palynostratigraphic succession of the uppermost Famennian in the eastern Dinant Synclinorium reveals the occurrence of a disturbed assemblage of poor and poorly diversified assemblage including typical spores of the LE biozone together with abundant abnormal forms (R. lepidophyta var. tener, Raistrickia variabilis, Fig. 6). This disrupted assemblage is interpreted as the result of fluctuating climatic conditions on land (possibly long drought and/or cold seasons), possibly in link with the Hangenberg Biocrisis. It would be one of the rare witnesses of the crisis on latest Devonian flora. However, as suggested by time-equivalent assemblages from Ireland (Van Veen, 1981a, b), this disruption was short-lasting and palynomorphs show a rapid post-crisis re-increase in diversity and the reduction of abnormal forms to normal level.

The last Famennian biozone (LN) is reconsidered as its guide taxa Verrucosisporites nitidus is absent or difficult to observe in several sections and should be viewed as an ecozone rather than a biozone. Consequently, we here propose to remove it from biostratigraphic schemes. Moreover, the absence of the LN zone in Belgium should not be used as an argument to support the occurrence of a sedimentary gap at the top of the Famennian (e.g. Becker et al., 2016 and references within). Consequently, there is no argument supporting the existence of a hiatus in Belgian sections (see also Poty, 2016, this volume).

Refinements of the biostratigraphic scheme is obviously needed and in the framework of the working group currently evaluating the definition of the DCB, the tener event should be considered as a potential marker of the Hangenberg Biocrisis on land and proximal settings.

\section{Acknowledgements}

The authors are particularly grateful to Eddy Poty for stimulating discussion on the DCB and Hangenberg event and inspiring fieldwork. They deeply thank Maurice Streel for the valuable help for the identification of spores. The authors are grateful also to Marcela Mezzatesta-Giraldo and Joël Laval for their invaluable technical assistance. The manuscript benefits from the review of Markus Aretz (Toulouse) and John Marshall (Southampton).

\section{References}

Algeo, T.J. \& Scheckler, S.E., 1998. Terrestrial-marine teleconnections in the Devonian: links between the evolution of land plants, weathering processes, and marine anoxic events. Philosophical Transactions of the Royal Society of London, Series B: Biological Sciences, 353, 113-130.
Alpern, B. \& Streel, M., 1973. Palynologie et stratigraphie du Paléozoique moyen et supérieur. Mémoires du Bureau de Recherches Géologiques et Minières, 77/1, 217-241.

Avkhimovitch, V.I., Byvsheva, T.V., Higgs, K., Streel, M. \& Umnova, V.T., 1988. Miospore systematics and stratigraphic correlation of Devonian-Carboniferous Boundary deposits in the European part of the USSR and Western Europe. Courier Forschungsinstitut Senckenberg, 100, 169-191.

Barskov, I.S., Simakov, K.V., Alekseev, A.S., Bogolovsky, N.I., Byvsheva, T.V., Gagiev, M.H., Kononova, L.N., Kochetkova, N.M., Kusina, L.F. \& Reitlinger, E.A., 1984. Devonian-Carboniferous transitional deposits of the Berchogursection, Mugodzary, USSR (preliminary report). Courier Forschungsinstitut Senckenberg, 67, 207-230.

Becker, G. \& Bless, M.J.M., 1974. Ostracode stratigraphy of the ArdennoRhenish Devonian and Dinantian. Publication of the International Symposium on Belgian Micropaleontological Limits from Emsian to Visean, Namur, 1, 1-52.

Becker, R.T., Kaiser, A.I. \& Aretz, M., 2016 (in press). Review of the chrono-, litho- and biostratigraphy across the global Hangenberg Crisis and Devonian-Carboniferous Boundary. In Becker, R.T., Königshof, P. \& Brett, C.E. (eds), Devonian Climate, Sea Level and Evolutionary Events. Geological Society, London, Special Publications, 423. http://doi.org/10.1144/SP423.10.

Bethune, de, 1954. Carte géologique de la Belgique au 1/500000. Atlas de Belgique, planche 8, Académie royale de Belgique, Bruxelles.

Bouckaert, J., Streel, M. \& Thorez, J., 1970. Le Famennien et les couches de transition Dévonien-Carbonifère dans la vallée de l'Ourthe (sud de Liège, Synclinorium de Dinant). In Streel, M. \& Wagner, R. (eds), Compte-rendus de la 8 e réunion de la Commission internationale de Microflore du Paléozoïque et de l'Assemblée générale de l'IUGS, Liège, 1970. Subcommission on Carboniferous Stratigraphy. Les Congrès et Colloques de l'Université de Liège, 55, 25-46.

Byvsheva, T.V., Higgs, K. \& Streel, M., 1984. Spore correlations between the Rhenish Slate Mountains and the Russian Platform near the Devonian-Carboniferous boundary. Courier Forschungsinstitut Senckenberg, 67, 37-45.

Cascales-Miñana, B., 2014. The plant fossil record reflects just two great extinction events. Terra Nova, 26, 195-200.

Casier, J.-G., Mamet, B., Préat,A. \& Sandberg, C.A., 2004. Sedimentology, conodonts and ostracods of the Devonian-Carboniferous strata of the Anseremme railway bridge section, Dinant Basin, Belgium. Bulletin de l'Institut Royal des Sciences Naturelles de Belgique, Sciences de la Terre, 74, 45-68.

Casier, J.G., Lebon, A., Mamet, B., \& Préat, A., 2005. Ostracods and lithofacies close to the Devonian-Carboniferous boundary in the Chanxhe and Rivage sections, northeastern part of the Dinant Basin, Belgium. Bulletin de l'Institut Royal des Sciences naturelles de Belgique, Sciences de la Terre, 75, 95-126.

Chibrikova, E.V., Kedo, G.I. \& Streel, M., 1978. [Important spores for the delineation of the Devonian-Carboniferous Boundary through USSR and Western Europe]. In Compte Rendu 8ème Congrès international de Stratigraphie et de Géologie du Carbonifère, Moscou 1975, 1, 198-203. [In Russian].

Combaz A. \& Streel M., 1971. Microfossiles végétaux du Tournaisien inférieur dans le core-drill de Brévillers (Pas-de-Calais, France). In Streel, M. \& Wagner, R. (eds), Compte-rendus de la 8e réunion de la Commission internationale de Microflore du Paléozoïque et de l'Assemblée générale de l'IUGS, Liège, 1970. Subcommission on Carboniferous Stratigraphy. Les Congrès et Colloques de 1'Université de Liège, 55, 227-240.

Conil, R., 1964. Localités et coupes-types pour l'étude du Tournaisien inférieur. Mémoires de l'Académie royale de Belgique, Classe des Sciences, 15/4, 1-87.

Conil, R., Dreesen, R., Lentz, M.A., Lys, M., \& Plodowski, G., 1986. The Devono-Carboniferous transition in the Franco-Belgian basin with reference to Foraminifera and brachiopods. Annales de la Société géologique de Belgique, 109/1, 19-26.

Decombeix, A.-L., Meyer-Berthaud, B., Galtier, J., Talent, J.A. \& Mawson, R., 2011a. Arborescent lignophytes in the Tournaisian vegetation of Queensland (Australia): Palaeoecological and palaeogeographical significance. Palaeogeography, Palaeoclimatology, Palaeoecology, 301, 39-55.

Decombeix, A.-L., Meyer-Berthaud, B. \& Galtier, J., 2011b. Transitional changes in arborescent lignophytes at the Devonian-Carboniferous boundary. Journal of the Geological Society, 168, 547-557.

Denayer, J., Prestianni, C., Sautois, M., Poty, E. \& Mottequin, B., 2015. The Devonian-Carboniferous Boundary and the Lower Carboniferous in the type area. In Denayer, J., Mottequin, B. \& Prestianni, C. (eds), IGCP596-SDS Symposium, Climate Change and Biodiversity patterns in the Mid-Palaeozoic, Brussels, September 2015, Field guidebooks. STRATA, 17, 59-81.

Dolby, G. \& Neves, R., 1970. Palynological evidence concerning the 
Devonian - Carboniferous Boundary in the Mendips, England. Comptes rendus du sixième congrès sur l'avancement de l'étude de la stratigraphie et la géologie du Carbonifère, Sheffield, 1967, 2, 631-646.

Dreesen R., Poty, E., Streel M. \& Thorez J., 1993. Late Famennian to Namurian in the Eastern Ardenne, Belgium. IUGS Subcommission on Carboniferous Stratigraphy, Guidebook, Liège, 60 p.

Fairon-Demaret, M. 1986. Some uppermost Devonian megafloras: a stratigraphical review. Annales de la Société géologique de Belgique, $109,43-48$.

Filipiak, P., 2004. Miospore stratigraphy of Upper Famennian and Lower Carboniferous deposits of the Holy Cross Mountains (central Poland). Review of Palaeobotany and Palynology, 128, 291-322.

Filipiak, P. \& Racki, G., 2010. Proliferation of abnormal palynoflora during the end-Devonian biotic crisis. Geological Quarterly, 54/1, $1-14$

Foster, C.B. \& Afonin, S.A., 2005. Abnormal pollen grains: an outcome of deteriorating atmospheric conditions around the Permian-Triassic boundary. Journal of the Geological Society, 162, 653-659.

Gayer, R.A., Allen, K.C., Bassett, M.G. \& Edwards, D., 1973. The structure of the Taff Gorge area, Glamorgan and the stratigraphy of the Old Red Sandstone - Carboniferous Limestone Transition. Geological Journal, 8, 345-374.

Hance, L. \& Poty, E., 2006. Hastarian. Geologica Belgica, 9/1-2, 111116.

Higgs, K., 1975. Upper Devonian and Lower Carboniferous miospore assemblages from Hook Head, county Wexford, Ireland. Micropaleontology, 21, 393-419.

Higgs, K. \& Streel, M., 1994. Palynological age for the lower part of the Hangenberg Shales in Sauerland, Germany. Annales de la Société géologique de Belgique, 116, 243-247.

Higgs, K., Clayton, G. \& Keegan, J.B., 1988. Stratigraphic and systematic palynology of the Tournaisian rocks of Ireland. Geological Survey of Ireland, Special paper No. 7, 8-47.

Jarvis, E. 1990. New palynological data on the age of the Kiltorcan Flora of Co. Kilkenny, Ireland. Journal of Micropaleontology, 9, 87-94.

Kaiser, S.I., Aretz, M. \& Becker, R.T., 2015 (in press). The global Hangenberg Crisis (Devonian-Carboniferous transition): review of a first-order mass extinction. In Becker, R.T., Königshof, P. \& Brett, C.E. (eds), Devonian Climate, Sea Level and Evolutionary Events. Geological Society, London, Special Publications, 423. http://doi. org/10.1144/SP423.9.

Kar, R.K. \& Dilcher, D.L., 2002. An argument for the origins of heterospory in aquatic environments. Paleobotanist, 51, 1-11.

Kedo, G.I., 1957. [Spores from the Supra Salt Devonian deposits of the Pripyat Depression and their stratigraphic significance]. Akademia Nauk Belrussk SSR, Trudy Instituta Geologicheskikh Nauk, Seria Stratigrafia i Paleontologia, 2, 3-43. [In Russian].

Kedo, G.I., 1963. [Spores of the Tournaisian Stage of the Pripyat Depression and their stratigraphical significance]. Rep Palaeontologiskii I Stratigrafiskii Byelorussian SSR, 4, 3-121. [In Russian].

Koti S., Reddy K. R., Reddy V. R., Kakani G. \& Zhao D. L., 2005. Interactive effects of carbon dioxide, temperature, and ultraviolet-B radiation on soybean (Glycine max L.) flower and pollen morphology, pollen production, germination, and tube lengths. Journal of Explorative Botany, 56, 725-736.

Loboziak, S., Streel, M., Dusar, M., Boulvain, F. \& De Geyter, G., 1994 Late Devonian-Early Carboniferous miospores from the Menen Borehole, Namur Synclinorium, Belgium. Review of Palaeobotany and Palynology, 80/1-2, 55-63.

Maziane, N. \& Vanguestaine, M., 1997. Acritarchs from the Uppermos Famennian at Chanxhe and Tohogne (Eastern Belgium). In Fatka, O $\&$ Servais, T. (eds), Acritarcha in Praha. Acta Universitatis Carolinae, Geologica, 40, 527-530.

Maziane, N., Higgs, K.T. \& Streel, M., 1999. Revision of the late Famennian miospore zonation scheme in eastern Belgium. Journal of Micropalaeontology, 18, 17-25.

Maziane, N., Higgs, K. \& Streel, M., 2002. Biometry and paleoenvironment of Retispora lepidophyta (Kedo) Playford 1976 and associated miospores in the latest Famennian nearshore marine facies, eastern Ardenne (Belgium). Review of Palaeobotany and Palynology, 118, 211-226.

McGhee, G.R., 2013. When invasion of land failed: the legacy of the Devonian extinctions. Columbia University Press, New York, $317 \mathrm{p}$

McGregor, D.C. 1970. Hymenozonotriletes lepidophytus Kedo and associated spores from the Devonian of Canada. In Streel, M. \& Wagner, R. (eds), Compte-rendus de la 8e réunion de la Commission internationale de Microflore du Paléozoïque et de l'Assemblée générale de l'IUGS, Liège, 1970. Subcommission on Carboniferous Stratigraphy. Les Congrès et Colloques de l'Université de Liège, 55, 315-326.

Mulcahy, D.L., 1981. Pollen tetrads in the detection of environmental mutagenesis. Environmental Health Perspectives, 37, 91-94.

Neves, R. \& Dolby, G., 1967. An assemblage of miospores from the Portishead beds (Upper Old Red Sandstone) of the Mendip Hills, England. Pollen et spores, 9, 607-614

Paproth, E. \& Streel, M. 1970. Corrélations biostratigraphiques près de la limite Dévonien/Carbonifère entre les faciès littoraux ardennais et les faciès bathyaux rhénans. In Streel, M. \& Wagner, R. (eds), Compte-rendus de la 8e réunion de la Commission internationale de Microflore du Paléozoïque et de l'Assemblée générale de l'IUGS, Liège, 1970. Subcommission on Carboniferous Stratigraphy. Les Congrès et Colloques de l'Université de Liège, 55, 365-398.

Paproth, E., Dreesen, R. \& Thorez, J. 1986. Famennian paleogeography and event stratigraphy of northwestern Europe. Annales de la Société géologique de Belgique, 109, 175-186.

Playford, G. \& McGregor, D.C., 1993. Miospores and organic-walled microphytoplankton of Devonian-Carboniferous boundary beds (Bakken Formation), southern Saskatchewan: a systematic and stratigraphic appraisal. Geological Survey of Canada Bulletin, 445, 1-107.

Poty, E., 2016 (this volume). The Dinantian (Mississipian) succession of southern Belgium and surrounding areas: stratigraphy improvement and inferred climate reconstruction. In Denayer, J. \& Aretz, M. (eds), Devonian and Carboniferous research: homage to Professor Edouard Poty. Geologica Belgica, 19/1-2, http://dx.doi.org/10.20341/ gb.2016.014

Poty, E., Denayer, J. \& Aretz, M., 2011. FT3: Uppermost Devonian and Lower Carboniferous of Southern Belgium. In Aretz, M. \& Poty, E. (eds), 11th International Symposium on Fossil Cnidaria and Porifera, Liège, 2011, Field Guides. Kölner Forum für Geologie und Paläontologie, 20, 99-150.

Pozhidaev, A.E., 2000. Pollen variety and aperture patterning. In Harley, M.M., Morton, C.M. \& Blackmore, S. (eds), Pollen and Spores: Morphology and Biology. Royal Botanic Gardens, Kew, 205-225.

Prestianni, C. \& Gerrienne, P., 2010. Early seed plant radiation: an ecological hypothesis. Geological Society, London, Special Publications, 339, 71-80.

Prestianni, C., Decombeix, A.-L., Thorez, J., Fokan, D. \& Gerrienne, P., 2010. Famennian charcoal of Belgium. Palaeogeography, Palaeoclimatology, Palaeoecology, 291, 60-71.

Prestianni, C., Rustán, J.J., Balseiro, D., Vaccari, E., Sterren, A.F. Steemans, P., Rubinstein, C. \& Astini, R.A., 2015. Early seed plants from Western Gondwana: Paleobiogeographical and ecological implications based on Tournaisian (Lower Carboniferous) records from Argentina. Palaeogeography, Palaeoclimatology, Palaeoecology, 417, 210-219.

Stempien-Salek, M., 2002. Miospore taxonomy and stratigraphy of Upper Devonian and lowermost Carboniferous in Western Pomerania (NW Poland). Annales Societatis Geologorum Poloniae, 72, 163-190.

Streel, M., 1966. Critères palynologiques pour une stratigraphie détaillée du Tn1a dans les bassins Ardenno-Rhénans. Annales de la Société géologique de Belgique, 89, 65-96.

Streel, M., 1999. Quantitative palynology of Famennian events in the Ardenne-Rhine regions. Abhandlungen der geologischen Bundesanstalt, 54, 201-212.

Streel, M., 2015. Palynomorphs (miospores, acritarchs, prasinophytes) before and during the Hangenberg crisis. In Mottequin, B., Denayer, J., Königshof, P., Prestianni, C. \& Olive, S. (eds), IGCP596-SDS Symposium, Climate Change and Biodiversity patterns in the MidPalaeozoic, Brussels, September 2015, Abstracts. STRATA, 16, 140143.

Streel, M. \& Hartkopf-Fröder, C., 2005. Late Famennian correlation by miospores between the Refrath 1 Borehole (Bergisch GladbachPaffrath Syncline, Germany) and the reference section of Chanxhe (Dinant Syncline, Belgium). In Steemans, P. \& Javaux, E. (eds), Pre-Cambrian to Palaeozoic Palaeopalynology and Palaeobotany. Carnets de Géologie/Notebooks on Geology, memoir 2005/02, abstract 10 .

Streel, M. \& Marshall, J.E.A., 2006. Devonian-Carboniferous boundary global correlation and their paleogeograhic implications for the assembly of Pangea. In Wong, T.E. (ed.), Proceedings of the XVth International Congress on Carboniferous and Permian Stratigraphy, Utrecht, the Netherlands, 10-16 August 2003. Royal Netherlands Academy of Arts and Sciences, 481-496.

Streel, M. \& Scheckler, S., 1990. Miospore lateral distribution in upper Famennian alluvial, lagoonal to tidal facies from eastern United States and Belgium. Review of Palaeobotany and Palynology, 64 , 315-324.

Streel M., Higgs K., Loboziak S., Riegel W. \& Steemans P., 1987. Spore stratigraphy and correlation with faunas and floras in the type marine Devonian of the Ardenne-Rhenish regions. Review of Palaeobotany and Palynology, 50, 211-229.

Streel, M., Caputo, M.V., Loboziak, S. \& Melo, J.H.G., 2000. Late Frasnian - Famennian climates based on palynomorph analyses 
and the question of the Late Devonian glaciations. Earth-Science Reviews, 52, 121-173.

Streel, M., Caputo, M.V., Melo, J.H.G. \& Perrez-Leyton, M., 2013. What do the latest Famennian and Viséan diamictites from Western Gondwana tell us? Palaeobiodiversity and Palaeoenvironments, 93, 299-316.

Thorez, J. \& Dreesen, R., 1986. A model of a regressive depositional system around the Old Red Continent as exemplified by a field trip in the Upper Famennian "Psammites du Condroz" in Belgium. Annales de la Société géologique de Belgique, 109, 285-323.

Thorez, J., Dreesen, R. \& Streel, M., 2006. Famennian. Geologica Belgica, 9/1-2, 27-45.

Traverse, A., 1988. Plant evolution dances to a different beat. Plant and animal evolutionary mechanisms compared. Historical Biology, 1, 227-301.

Turnau, E., 1975. Microflora of the Famennian and Tournaisian deposits from boreholes of Northern Poland. Acta Geologica Polonica, 25, 505-528.

Turnau, E., 1978. Spore zonation of uppermost Devonian and Lower Carboniferous deposits of Western Pomerania. Mededelingen Rijks Geologische Dienst, 30, 1-25.

Turnau, E., Avkhimovitch, V.I., Byvsheva, T.V., Clayton, G., Higgs, K. \& Owens, B., 1994. Taxonomy and stratigraphical distribution of Verrucosisporites nitidus Playford, 1964 and related species. Review of Palaeobotany and Palynology, 81, 289-295.

Van Steenwinkel, M. 1984. The Devonian-Carboniferous boundary in the vicinity of Dinant, Belgium. Courier Forschungsinstitut Senckenberg, 67, 57-69.

Van Steenwinkel, M., 1993. The Devonian-Carboniferous boundary: comparison between the Dinant synclinorium and the northern border of the Rhenish Slate Mountains, a sequence-stratigraphic view. Annales de la Société géologique de Belgique, 115, 665-681.

Van Veen, P.M., 1981a. Aspects of Late Devonian and Early Carboniferous palynology of Southern Ireland. V. The change in composition of palynological assemblages at the Devonian-Carboniferous Boundary. Review of Palaeobotany and Palynology, 34, 67-94.

Van Veen, P.M., 1981b. Aspects of Late Devonian and Early Carboniferous palynology of Southern Ireland, IV: Morphological variation within Diducites a new form genus to accomodate camerate spores with two layered outer wall. Review of Palaeobotany and Palynology, 31, 261-287.

Visscher, H., Looy, C.V., Collinson, M.E., Brinkhaus, H., van Konijnenburg-van Cittert, J.H.A., Kürschner, W.M. \& Sephton, M., 2004. Environmental mutagenesis during the end-Permian ecological crisis. Proceedings of the National Academy of Sciences of the USA, 101, 12952-12956.

Ziegler, W. \& Sandberg, C.A., 1990. The Late Devonian standard conodont zonation. Courier Forschungsinstitut Senckenberg, 121, $1-115$. 